\title{
EFEK KEBIJAKAN MONETER TERHADAP RETURN HARGA EMAS DI INDONESIA
}

\author{
Abdul Khaliq \\ Fakultas Ekonomi, Universitas Andalas
}

\begin{abstract}
This studyobserves the short-run and long-run relationship between monetary policies andgold price return movements in Indonesia. Using monthly data over the period 1997M09-2017M10,the empirical findings are carried out by utilizing error correction model (ECM)derived from single quadratic cost function to provide evidence in favor of relationship between nominal effective exchange rate, interest rate, and money supplyand gold price return movements.The empirical evidence suggests that the ECM estimates well characterize how the nominal effective exchange rate relates to the gold price return movements, both in the long-run and short-run. Moreover, money supply and interest rate only have negative and statistically significant effects on price gold return movements in the long run. These results imply that observing nominal effective exchange rate can help predict gold price return movements in Indonesia, which would significantly help monetary authorities in optimizing monetary policy.
\end{abstract}

Keywords : Gold Price Return, Monetary Policies, Error Correction Model (ECM)

\begin{abstract}
ABSTRAK
Penelitian ini mengobservasi hubungan kebijakan moneter dengan return harga emas di Indonesia baik jangka pendek maupun jangka panjang. Menggunakan data bulanan 1997M09-2017M10, temuan empiris dilakukan dengan error correction model (ECM) yang diturunkan dari fungsi biaya kuadratik untuk melihat efek nilai tukar nominal efektif, tingkat bunga dan jumlah uang beredar terhadap pergerakan return harga emas. Fakta empiris menemukan bahwa ECM mengestimasi dengan baik efek nilai tukar nominal efektif terhadap pergerakan return nilai tukar untuk jangka pendek dan jangka panjang. Sementara itu, jumlah uang beredar dan tingkat bunga hanya berdampak pada jangka panjang terhadap return harga emas. Hasil ini mengimplikasikan bahwa nilai tukar nominal efektif dapat memprediksi pergerakan return dari harga emas di Indonesia yang akan dapat membantu otoritas moneter mengoptimalkan kebijakannya.

Keywords : Return Harga Emas, Kebijakan Moneter, Error Correction Model (ECM)
\end{abstract}




\section{PENDAHULUAN}

Secara tradisional emas merupakan bentuk investasi yang aman (ahedge) dan bebas resiko (asafe haven). Berbeda dengan mata uang kertas, emas memiliki nilai intrisik dan mempunyai daya beli yang stabil terutama ketika perekonomian menghadapiresiko tinggidari ketidakpastian seperti pada saat inflasi, depresiasi mata uang,dan kolapsnya perbankan. Seharusnya return harga emas secara konsisten mengalami kenaikan bersamaan dengan ketidakpastian ekonomi.Namun, dampak dari ketidakpastian ekonomi terhadap pergerakan return harga emas tidak jelas dan mengandung banyak perdebatan. Faktanya, pergerakan return harga emas pada masa ekonomi menghadapi resesi mengalami volatilitas yang tinggi.

Emas telah memainkan peran yang amat penting dalam perekonomian. Pada masa lampau, emas telah digunakan sebagai mata uang dan penyimpan nilai kekayaan bahkan menjadipatokan kekuatan ekonomi suatu bangsa. Peran penting emas dalam perekonomian masih berlanjut hingga saat sekarang dimana cadangan emas digunakan sebagai indikator dalam penawaran mata uang oleh pemerintah dan bank sentral. Harga emas menjadi indikasi dari mata uang. Selain itu, emas juga menjadi alternatif investasi portofolio disamping saham. Oleh karena itu, ketika perekonomian mengalami gangguandan ketidakpastian yang diindikasikan oleh terjadinya inflasi, melemahnya mata uang, dan menurunnya nilai saham maka investor mencari alternatif untuk mengalihkan aset finansialnya. Salah satu alternatif yang paling aman dalam mendiversifikasi aset investasi adalah emas. Emas menjadi semakin penting sebagai pelindung nilai (hedging) aset finansial.
Meskipun emas dianggap sebagai aset finansial yang paling aman dan bebas resiko (safe haven) dimasa perekonomian menghadapi tekanan, pergerakan harga emas menunjukkan volatilitas dari waktu ke waktu termasuk ketika perekonomian mengalami ketidakstabilan. Fakta ini dapat dilihat dari Gambar 1 dimana pergerakan harga emas di Indonesia mengalami fluktuasi dalam dua tahun belakangan ini. Kondisi ini memunculkan pertanyaan dimana seharusnya harga emas mengalami kenaikan pada saat terjadinya tekanan pada perekonomian tetapi justru menghadapiturbulensi. Keadaan turbulensi ini menyebabkan pengambil kebijakan moneter dan investor mengalami kesulitan dalam menyusun strategi dan membuat keputusan bagi pengamanan aset finansial.

\section{Gambar1.Volatilitas harga emas}

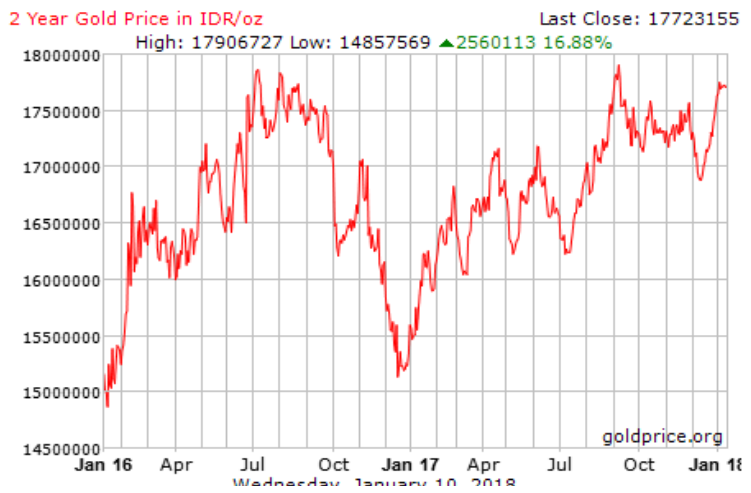

Sumber: goldprice.org

Berdasarkan fakta diatas, pengambil kebijakan moneter dan investor sangat perlu memahami penyebab fluktuasi pergerakan harga emas dengan menelusuri faktor-faktor yang mempengaruhinya. Pengetahuan ini penting sebagai upaya untuk membuat keputusan dan menyusun strategi dalam mendiversifikasi aset finansial sehingga tetap aman dan bebas dari resiko. Untuk mengetahui faktor faktor yang relevan mempengaruhi pergerakan harga emas baik pada jangka pendek maupun jangka panjang maka 
memerlukan kajian yang spesifik dengan metode yang spesifik pula.

Salah satu metode yang dapat digunakan dalam mendeteksi pergerakan harga emas adalah error correction model (ECM). Metode ini berguna untuk mendeteksi penyesuaian ketidakseimbangan jangka pendek menuju keseimbangan jangka panjang (Gujarati, 2003). Metode ini telah diadopsi oleh beberapa peneliti, akademisi, dan praktisi dalam mendeteksi volatilitas harga emas di dunia seperti The World Gold Council (2011), namun hanya sedikit yang mengaplikasikannya untuk meneliti pergerakan harga emas di Indonesia seperti Enidan Halim (2014). Oleh karena itu, tulisan ini berkontribusi dalam pengembangan literatur teori investasi dan memperkaya temuan empiris di Indonesia sebagai bagian langkah penting dalam memformulasi strategi bagi pengambil kebijakan moneter dan investor dalam melindungi aset finansialnya.

\section{KAJIAN LITERATUR}

\section{Karakteristik Emas Dalam Ekonomi}

Emas telah digunakan sebagai penyimpan nilai dan mata uang sejak zaman kuno. Semenjak abad tujuh belasemas secara formal diperdagangkan dan pada abad ke sembilan belas emas dijadikan sebagai sistem nilai tukar tetap (Gold Standard). Selanjutnya, pada abad dua puluh emas menjadi tulang punggung mekanisme nilai tukar (Bretton Woods), tetapi sistem ini runtuh pada awal 1970-an dan membiarkan harga emas mengambang bebas (The World Gold Council, 2011).

Sejarah emas sebagai penyimpan nilai dan mata uang menyebabkan emas memiliki karakteristik yang berbeda dari komoditi lain dalam ekonomi. Emas merupakan logam mulia yang nilainya tidak mengalami degredasi antar waktu. Emas hasil tambang saat ini dapat dipertukarkan dengan emas yang ditambang ratusan tahun yang lalu. Fakta ini pula yang menyebabkan emas memiliki karakteristik yang unik dalam jangka waktu yang lama sebagai penyimpan nilai (The World Gold Council, 2011).

Karena emas memiliki karakteristik yang unik, emas dianggap sebagai logam mulia paling efektif untuk berinvestasi (Eni dan Halim, 2014). Bahkan emas merupakan salah satu alternatif investasi paling aman dan bebas resiko di bandingkan dengan aset portofolio lainnya (Sunariyah, 2006). Emas semakin penting sebagai alternatif mendiversifikasikan aset portofolio ketika ekonomi dan keuangan menghadapi ketidakpastian. Emas dilihat sebagai mata uang yang diterima secara global tanpa kehilangan kemampuan daya belinya dan memiliki kemampuan mempertahankan nilainya ketika menghadapi erosi pada sistem perbankan dan moneter (Bialkowski et al., 2013).

\section{Emas dan Sektor Moneter}

Keterkaitan emas dengan sektor moneter telah menjadi studi yang menarik dan berkembang luas. Emas tidak hanya sebagai 'safe haven', tetapi berperan dalam sistem moneter sebagai uang riil (Apergis dan Papoulakos, 2013). Lebih lanjut, Apergis dan Papoulakos (2013) melakukan kajian hubungan dolar Australia dengan harga emas menggunakan data harian dalam periode 2000-2011 dan metode error correction model dan pendekatan generalized autoregressive heteroskedastic (GARCH). Mereka menemukan fakta hubungan dua arah (bi-directional) antara nilai tukar nominal/nilai tukar riil dengan harga emas dalam bentuk rata-rata dan volatilitas. Nilai tukar dapat digunakan untuk memperkirakan harga emas dimasa depan. 
Wang dan Lee (2011) menguji apakah emas dapat menjadi pelindung nilai dari nilai tukar di Jepang menggunakan data dari 1986 sampai 2007. Mereka menggunakan depresiasi nilai Yen sebagai variabel threshold untuk membedakan antara rejim depresiasi yang tinggi dan rejim depresiasi yang rendah (atau apresiasi). Dengan membentuk threshold vector autoregressive model(TVAR), Wang dan Lee (2011) menginvestigasi hubungan kausalitas antara emas dengan depresiasi nilai Yen. Mereka menemukan ketika nilai Yen terdepresiasi lebih dari 2,62\% maka investasi pada emas dapat menghindari kerugian dari depresiasi. Oleh karena itu, mereka menyimpulkan bahwa emas bertindak secara efektif sebagai pelindung nilai dari kejatuhan nilai tukar yang tergantung pada tingkat depresiasi Yen sendiri. Informasi ini berguna bagi otoritas moneter dan investor yang memegang emas sebagai alternatif mendiversifikasikan aset portofolionya.

The World Gold Council (2011) melakukan kajian faktor-faktor yang mempengaruhi pergerakan harga emas untuk jangka pendek dan jangka panjang menggunakan data US dari 1976 hingga 2010.Faktor-faktor yang dimasukkan dalam model adalah tekanan finansial, tingkat bunga riil, inflasi, jumlah uang beredar, nilai tukar, dan kondisi politik. Hasil studi memperlihatkan bahwa tingginya tingkat bunga riil meningkatkan opportunity cost memegang emas, sementara tingkat bunga riil yang rendah atau negatif meningkatkan permintaan terhadap emas. Selanjutnya, peningkatan jumlah uang beredar oleh bank sentral mendorong investor memegang emas sebagai pelindung nilai untukmengantisipasi kesalahan kebijakan yang dapat mendorong kenaikan inflasi.
Artigas (2010) meneliti hubungan jumlah uang beredar terhadap harga emas secara global. Menggunakan metode multiple regression dengan lag-6 terhadap data US, Eropa, India dan Turki, Artigas (2010) menemukan bahwa perubahan jumlah uang berdar dapat berdampak pada pergerakan harga emas. Pertumbuhan positif jumlah uang beredar dapat menjelaskan kenaikan harga emas global dari 6 hingga 9 bulan ke depannya. Efek ini tidak berlaku untuk US, tetapi memiliki efek positif bagi India, Eropa, dan Turki. Selanjutnya, Artigas (2010) juga menunjukkan emas sebagai indikator dari perputaran uang dimasa mendatang. Kenaikan harga emas memberikan sinyal bahwa pasar mempunyai ekspektasi terhadap kenaikan perputaran uang sehingga meningkatkan inflasi dimasa depan.

\section{METODOLOGIPENELITIAN}

\section{Data dan Sumber Data}

Variabel dalam penelitian ini terdiri dari return harga emas (PGR) nilai tukar nominal efektif (NEER), tingkat bunga (IR), dan jumlah uang beredar (M2). Penelitian menggunakan data sekunder bulanan periode September 1997 (1997M09) sampai dengan Oktober 2017 (2017M10). Jumlah observasi sebesar 242. Data diperoleh dari berbagai sumber seperti Bank Indonesia, World Gold Council, dan The Bank for International Settlements (BIS). Untuk data nominal ditransformasi menggunakan logaritma natural. 
Tabel 1. Data dan Sumber Data

\begin{tabular}{|l|c|l|c|l|}
\hline No & $\begin{array}{c}\text { Nama } \\
\text { Variabel }\end{array}$ & Definisi & Satuan & $\begin{array}{l}\text { Sumber } \\
\text { Data }\end{array}$ \\
\hline 1. & PGR & $\begin{array}{l}\text { Return harga } \\
\text { emas } \\
(\text { lnPGR(t/t- } \\
1) \text { ) }\end{array}$ & $\begin{array}{l}\text { Rp/troy } \\
\text { ounce }\end{array}$ & $\begin{array}{l}\text { http://ww } \\
\text { w.gold.or } \\
\text { g/ }\end{array}$ \\
\hline 2. & NEER & $\begin{array}{l}\text { Harga relatif } \\
\text { dari barang } \\
\text { barang pada } \\
\text { kedua } \\
\text { negara yang } \\
\text { melakukan } \\
\text { perdagangan }\end{array}$ & Indeks & $\underline{\underline{\mathrm{http} / / \mathrm{ww}}}$ \\
$\underline{\underline{\text { w.bis.org/ }}}$ \\
$\underline{\text { statistics/e }}$ \\
$\underline{\text { er/ }}$ \\
$\underline{\text { index.htm }}$ \\
\hline 3. & IR & $\begin{array}{l}\text { Nominal BI } \\
\text { rate }\end{array}$ & $\%$ & $\begin{array}{l}\text { Bank } \\
\text { Indonesia }\end{array}$ \\
\hline 4. & M2 & $\begin{array}{l}\text { Jumlah uang } \\
\text { inti }\end{array}$ & Rp & $\begin{array}{l}\text { Bank } \\
\text { Indonesia }\end{array}$ \\
\hline
\end{tabular}

\section{Spesifikasi Model}

Penelitian ini memodifikasi model pergerakan harga emas yang dikembangkan oleh The World Gold Council (2011). Estimasimemfokuskan pada efek kebijakan moneter terhadappergerakan return harga emas (PGR) untuk Indonesia dinyatakan dengan fungsi berikut:

$$
P G R=f(N E E R, I R, M 2)
$$

dimana NEER adalah nilai tukar nominal efektif, IR adalah tingkat bunga, dan M2 adalah penawaran uang.

Selanjutnya fungsi (1) diestimasi menggunakan persamaan tunggalerror correction model (ECM). Penggunaan model ini untuk menelusuri hubungan jangka panjang dan jangka pendek efek kebijakan moneter yang mempengaruhi pergerakan return harga emas.

Langkah awal pembentukan model empiris adalah menurunkan persamaan (1) sehingga menghasilkan persamaan berikut:

$$
\begin{aligned}
P G R_{t}= & a_{0}+a_{1} R E E R_{t}+a_{2} I R_{t} \\
& +a_{3} M 2_{t}+e_{t}
\end{aligned}
$$

atau dalam bentuk log-linear menjadi

$$
\begin{aligned}
\ln P G R_{t}= & a_{0}+a_{1} \ln R E E R_{t}+a_{2} I R_{t} \\
& +a_{3} \ln M 2_{t}+e_{t}
\end{aligned}
$$

Persamaan (3) merupakan keseimbangan jangka panjang. Namun, kondisi ini jarang terjadi karena terciptanya ketidakseimbangan error atau Imbalances and disequilibrium error (DE):

$D E_{t}=\ln P G R_{t}-\ln P G R_{t}^{*}$

atau

$$
\begin{gathered}
D E_{t}=\ln P G R_{t}-a_{0}-a_{1} \ln \text { REER }_{t} \\
-a_{2} I R_{t}-a_{3} \ln M 2_{t}
\end{gathered}
$$

Selanjutnya, penurunan error correction model (ECM) mengikuti formulasi fungsi biaya kuadrat tunggal (single quadratic cost function) yang dikembangkan Domowitz dan Elbadawi (1987) berikut:

$$
\begin{aligned}
C_{t}= & b_{1}\left(\ln P G R_{t}-\ln P G R_{t}^{*}\right)^{2} \\
& +b_{2}\left[\left(\ln P G R_{t}-\ln P G R_{t-1}\right)\right. \\
& \left.-f\left(Z_{t}-Z_{t-1}\right)\right]^{2}
\end{aligned}
$$

dimana $\quad b_{1}\left(\ln P G R_{t}-\ln P G R_{t}^{*}\right)^{2} \quad$ adalah biaya ketidakseimbangan (the cost of imbalances) dan $b_{2}\left[\left(\ln P G R_{t}-\ln P G R_{t-1}\right)\right]$ adalah biaya penyesuaian (adjustment cost). Notasi $f$ adalah baris vektor yang memberikan penimbang pada $\left(Z_{t}-Z_{t-1}\right)$, dimana $Z$ adalah vektor variabel yang berdampak pada pergerakan return harga emas $P G R$.Minimisasi fungsi biaya kuadrat tunggal mengikuti tahapan berikut: 


$$
\begin{aligned}
\frac{d C_{t}}{d \ln P G R_{t}}= & 2 b_{1}\left(\ln P G R_{t}-\ln P G R_{t}^{*}\right) \\
& +2 b_{2}\left[\left(\ln P G R_{t}-\ln P G R_{t-1}\right)\right. \\
& \left.-f\left(Z_{t}-Z_{t-1}\right)\right]=0
\end{aligned}
$$

$2 b_{1} \ln P G R_{t}-2 b_{1} \ln P G R_{t}^{*}+2 b_{2} \ln P G R_{t}$ $-2 b_{2} \ln P G R_{t-1}-2 b_{2} f\left(Z_{t}-Z_{t-1}\right)=0$

$2\left(b_{1}+b_{2}\right) \ln P G R_{t}=2 b_{1} \ln P G R_{t}^{*}$ $+2 b_{2} \ln P G R_{t-1}+2 b_{2} f\left(Z_{t}-Z_{t-1}\right)$

$\left(b_{1}+b_{2}\right) \ln P G R_{t}=b_{1} \ln P G R_{t}^{*}$ $+b_{2} \ln P G R_{t-1}+b_{2} f\left(Z_{t}-Z_{t-1}\right)$

Selanjutnya, dengan memasukkan model jangka panjang (long-term model)bersamaan dengan mengikutsertakan NEER, IR , dan $M 2$ sebagai fungsi dari $Z_{t}$, sehingga:

$$
\begin{aligned}
\left(b_{1}+b_{2}\right) \ln P G R_{t}= & b_{1} \\
& a_{0}+a_{1} \ln R E E R_{t} \\
& +a_{2} I R_{t}+a_{3} \ln M 2_{t} \\
& +b_{2} \ln P G R_{t-1}+b_{2} f_{1} \ln R E E R_{t} \\
& +b_{2} f_{2} I R_{t}+b_{2} f_{3} \ln M 2_{t} \\
& -b_{2} f_{1} \ln R E E R_{t-1}-b_{2} f_{2} I R_{t-1} \\
& -b_{2} f_{3} \ln M 2_{t-1}
\end{aligned}
$$$$
\left(b_{1}+b_{2}\right) \ln P G R_{t}=b_{1} a_{0}+b_{1} a_{1} \ln R E E R_{t}
$$$$
+b_{1} a_{2} I R_{t}+b_{1} a_{3} \ln M 2_{t}
$$$$
+b_{2} \ln P G R_{t-1}+b_{2} f_{1} \ln R E E R_{t}
$$$$
+b_{2} f_{2} I R_{t}+b_{2} f_{3} \ln M 2_{t}
$$$$
-b_{2} f_{1} \ln R E E R_{t-1}-b_{2} f_{2} I R_{t-1}
$$$$
-b_{2} f_{3} \ln M 2_{t-1}
$$

$$
\begin{aligned}
\ln P G R_{t}= & \frac{b_{1}}{\left(b_{1}+b_{2}\right)} a_{0}+\frac{b_{1}}{\left(b_{1}+b_{2}\right)} a_{1} \ln R E E R_{t} \\
& +\frac{b_{1}}{\left(b_{1}+b_{2}\right)} a_{2} I R_{t}+\frac{b_{1}}{\left(b_{1}+b_{2}\right)} a_{3} \ln M 2_{t} \\
& +\frac{b_{2}}{\left(b_{1}+b_{2}\right)} \ln P G R_{t-1}+\frac{b_{2}}{\left(b_{1}+b_{2}\right)} f_{1} \ln R E E R_{t} \\
& +\frac{b_{2}}{\left(b_{1}+b_{2}\right)} f_{2} I R_{t}+\frac{b_{2}}{\left(b_{1}+b_{2}\right)} f_{3} \ln M 2_{t} \\
& -\frac{b_{2}}{\left(b_{1}+b_{2}\right)} f_{1} \ln R E E R_{t-1}-\frac{b_{2}}{\left(b_{1}+b_{2}\right)} f_{2} I R_{t-1} \\
& -\frac{b_{2}}{\left(b_{1}+b_{2}\right)} f_{3} \ln M 2_{t-1}
\end{aligned}
$$

Jika,

$b=\frac{b_{1}}{\left(b_{1}+b_{2}\right)}$, lalu

$\frac{b_{2}}{\left(b_{1}+b_{2}\right)}=\frac{\left(b_{2}+b_{1}\right)-b_{1}}{\left(b_{1}+b_{2}\right)}=1-b$

Persamaan (7) dapat disederhanakan menjadi:

$\ln P G R_{t}=b a_{0}+b a_{1} \ln R E E R_{t}+b a_{2} I R_{t}$

$+b a_{3} \ln M 2_{t}+(1-b) \ln P G R_{t-1}$

$+(1-b) f_{1} \ln R E E R_{t}+(1-b) f_{2} I R_{t}$

$+(1-b) f_{3} \ln M 2_{t}-(1-b) f_{1} \ln R E E R_{t-1}$

$-(1-b) f_{2} I R_{t-1}-(1-b) f_{3} \ln M 2_{t-1}$

$\ln P G R_{t}=b a_{0}+\left[b a_{1}+(1-b) f_{1}\right] \ln R E E R_{t}$

$+\left[b a_{2}+(1-b) f_{2}\right] I R_{t}$

$+\left[b a_{3}+(1-b) f_{3}\right] \ln M 2_{t}-(1-b) f_{1} \ln R E E R_{t-1}$

$-(1-b) f_{2} I R_{t-1}-(1-b) f_{3} \ln M 2_{t-1}$

$+(1-b) \ln P G R_{t-1}$

$$
\begin{aligned}
\ln P G R_{t}= & g_{0}+g_{1} \ln R E E R_{t}+g_{2} I R_{t} \\
& +g_{3} \ln M 2_{t}+g_{4} \ln R E E R_{t-1} \\
& +g_{5} I R_{t-1}+g_{6} \ln M 2_{t-1} \\
& +g_{7} \ln P G R_{t-1}
\end{aligned}
$$

Dimana,

$$
\begin{aligned}
& g_{0}=b a_{0}, g_{1}=b a_{1}+(1-b) f_{1}, \\
& g_{2}=b a_{2}+(1-b) f_{2}, g_{3}=b a_{3}+(1-b) f_{3}, \\
& g_{4}=-(1-b) f_{1}, g_{5}=-(1-b) f_{2}, \\
& g_{6}=-(1-b) f_{3}, \text { dan } g_{7}=(1-b)
\end{aligned}
$$


Untuk menghindari terjadinya estimasi palsu/lancung (phony estimator) jika variabel tidak stasioner maka dilakukan reparameterisasi ke bentuk:

$\ln P G R_{t}-\ln P G R_{t-1}+\ln P G R_{t-1}=g_{0}+g_{1} \ln R E E R_{t}$

$$
-g_{1} \ln R_{E E R_{t-1}}
$$

$+g_{1} \ln R E E R_{t-1}$

$+g_{2} I R_{t}-g_{2} I R_{t-1}$

$+g_{2} I R_{t-1}+g_{3} \ln M 2_{t}$

$-g_{3} \ln M 2_{t-1}$

$+g_{3} \ln M 2_{t-1}$

$+g_{4} \ln$ REER $_{t-1}$

$+g_{5} I R_{t-1}$

$+g_{6} \ln M 2_{t-1}$

$+g_{7} \ln P G R_{t-1}$

karena $\Delta x_{t}=x_{t}-x_{t-1}$, maka persamaan

diatas menjadi:

$\Delta \ln P G R_{t}+\ln P G R_{t-1}=g_{0}+g_{1} \Delta \ln R E E R_{t}$

$$
\begin{aligned}
& +g_{1} \ln R E E R_{t-1}+g_{2} \Delta I R_{t} \\
& +g_{2} I R_{t-1}+g_{3} \Delta \ln M 2_{t} \\
& +g_{3} \ln M 2_{t-1}+g_{4} \ln R E E R_{t-1} \\
& +g_{5} I R_{t-1}+g_{6} \ln M 2_{t-1} \\
& +g_{7} \ln P G R_{t-1}
\end{aligned}
$$

$\Delta \ln P G R_{t}=g_{0}+g_{1} \Delta \ln R E E R_{t}+g_{2} \Delta I R_{t}$

$+g_{3} \Delta \ln M 2_{t}+\left(g_{1}+g_{4}\right) \ln$ REER $_{t-1}$

$+\left(g_{2}+g_{5}\right) I R_{t-1}+\left(g_{3}+g_{6}\right) \ln M 2_{t-1}$

$+\left(g_{7}-1\right) \ln P G R_{t-1}$

$\Delta \ln P G R_{t}=g_{1} \Delta \ln R E E R_{t}+g_{2} \Delta I R_{t}+g_{3} \Delta \ln M 2_{t}$

$+\left(g_{7}-1\right) \ln P G R_{t-1}+g_{0}+\left(g_{1}+g_{4}\right) \ln$ REER $_{t-1}$

$+\left(g_{2}+g_{5}\right) I R_{t-1}+\left(g_{3}+g_{6}\right) \ln M 2_{t-1}$

$\Delta \ln P G R_{t}=g_{1} \Delta \ln R E E R_{t}+g_{2} \Delta I R_{t}+g_{3} \Delta \ln M 2_{t}$

$$
\begin{aligned}
& -\left(1-g_{7}\right)\left[\ln P G R_{t-1}-\frac{g_{0}}{\left(1-g_{7}\right)}\right. \\
& -\frac{\left(g_{1}+g_{4}\right)}{\left(1-g_{7}\right)} \ln R E E R_{t-1}-\frac{\left(g_{2}+g_{5}\right)}{\left(1-g_{7}\right)} I R_{t-1} \\
& \left.-\frac{\left(g_{3}+g_{6}\right)}{\left(1-g_{7}\right)} \ln M 2_{t-1}\right]
\end{aligned}
$$

$\Delta \ln P G R_{t}=\alpha_{1} \Delta \ln R E E R_{t}+\alpha_{2} \Delta I R_{t}+\alpha_{3} \Delta \ln M 2_{t}$

$$
+\gamma\left[\ln P G R_{t-1}-\beta_{0}-\beta_{1} \ln R E E R_{t-1}\right.
$$$$
\left.-\beta_{2} R I R_{t-1}-\beta_{3} \ln M 2_{t-1}\right]
$$

Dimana,

$$
\begin{aligned}
& \alpha_{1}=g_{1}, \alpha_{2}=g_{2}, \alpha_{3}=g_{3}, \gamma=-\left(1-g_{7}\right) \\
& \beta_{0}=\frac{g_{0}}{\left(1-g_{7}\right)}, \beta_{1}=\frac{\left(g_{1}+g_{4}\right)}{\left(1-g_{7}\right)}, \\
& \beta_{2}=\frac{\left(g_{2}+g_{5}\right)}{\left(1-g_{7}\right)}, \operatorname{dan} \beta_{3}=\frac{\left(g_{3}+g_{6}\right)}{\left(1-g_{7}\right)}
\end{aligned}
$$

Persamaan (9) merupakan persamaan pendek dan jangka panjang yang akan mengestimasi pergerakan harga emas di Indonesia.

\section{METODE ANALISA}

\section{Uji Stasioneritas Data}

Uji stationeritas sangat penting untuk data runtun waktu. Dikatakan stasioner jika memenuhi asumsi mean dan variance-nya konstan dari waktu ke waktu dan covariance-nya antara dua data deret waktu hanya tergantung dari lag antara dua periode waktu tersebut (Gujarati, 2003). Secara statistik dinyatakan sebagai berikut:

$$
\text { Mean }: E\left(Y_{t}\right)=\mu
$$

Variance $: \operatorname{var}\left(Y_{t}\right)=E\left(Y_{t}-\mu\right)^{2}=\sigma^{2}$

$$
\text { Covariance : } \gamma_{k}=E\left[\left(Y_{t}-\mu\right)\left(Y_{t+k}-\mu\right)\right]
$$

Pengujian stasioneritas sebuah series menggunakan unit root test. Metode pengujian unit root test dapat dilakukan dengan metode Augamented Dickey Fuller (ADF) dan Phillips Perron (PP) sebagai berikut:

Augamented Dickey Fuller (ADF) test, (Gujarati, 2003) 
$\Delta Y_{t}=\beta_{1}+\beta_{2 t}+\delta Y_{t-1}+\alpha \sum_{i=1}^{m} \Delta Y_{t-1}+\varepsilon_{t}$

Phillips Perron (PP) test, (Phillips dan Perron, 1988)

$$
\Delta Y_{t}=\alpha+\beta Y_{t-1}+\varepsilon_{t}
$$

\section{Pengujian Kointegrasi}

Kointegrasi merupakan hubungan jangka panjang antara variabel-variabel yang tidak stasioner. Pengujian kointegrasi penting pula dilakukan untuk menghindari fenomena regresi palsu dan melengkapi uji stationeritas. Pengujian kointegrasi menggunakan metode Johansen Cointegration test (Johansen, 1995) sebagai berikut:

$\begin{array}{lc}\text { Trace } & \text { Statistic } \\ \lambda_{\text {Trace }}(r)=-T \sum_{i=r+1}^{n} \ln \left(1-\hat{\lambda}_{i}\right)\end{array}$

Max Statistic

$\lambda_{\text {Max }}(r, r+1)=-T \ln \left(1-\hat{\lambda}_{r+1}\right)$

\section{Estimasi Error Correction Model (ECM) Jangka Pendek dan Jangka Panjang}

Modelestimasi keterkaitan dinamis jangka pendek dan jangka panjang efek kebijakan moneter terhadap pergerakanreturn harga emas di Indonesia mengikuti persamaan (9) yang ditulis kembali dalam versi berikut:

$$
\begin{aligned}
D \ln P G R_{t}= & \alpha_{0}+\alpha_{1} D \ln R E E R_{t}+\alpha_{2} D I R_{t} \\
& +\alpha_{3} D \ln M 2_{t}+\gamma\left(\mathrm{B} \ln P G R_{t}\right. \\
& -\beta_{1} \mathrm{~B} \ln R E E R_{t}-\beta_{2} \mathrm{~B} I R_{t} \\
& \left.-\beta_{3} \mathrm{~B} \ln M 2_{t}+\varepsilon_{t}\right)
\end{aligned}
$$

dimana

$$
\begin{aligned}
& D=\text { First Difference } \\
& \mathrm{B}=\text { Backward lag operator }
\end{aligned}
$$

Dengan demikian koefisien $\gamma$ merupakan besaran penyesuaian bila terjadi fluktuasi pada sektor moneter dan finansial yang diamati Hasil pengujian metode Augmented Dickey Fuller (ADF)pada derajat keyakinan 99\% memperlihatkan bahwa nilai tukar nominal efektif (LnNEER) dan return harga emas pada tingkat konsumen (LnPGR)stasioner pada tingkat level, $\mathrm{I}(0)$. Sementara variabel lainnya, seperti jumlah uang beredar (lnM2) dan tingkat bunga (IR), stasioner pada first difference, I(1).

menyimpang dari hubungan jangka panjangnya.

\section{HASIL DAN PEMBAHASAN}

\section{Hasil Uji Prasyarat}

Untuk mengimplimentasikan ECM, uji prasyarat merupakan langkah penting yang harus dilakukan. Metode ECMakan dapat dipakai jika semua uji prasyarat telah terpenuhi. Adapun uji prasyarat yang harus dilakukan adalah uji stasioneritas datadan uji kointegrasi. Penelitian ini sudah melewati semua uji prasyarat sehingga metodeECM dapat diimplimentasikan.

\section{Uji Stasioneritas}

Penggunaan data runtun waktu dalam ECMmengharuskan pengujian stasioneritas data. Metode ECM menghendaki data stasioner atau terbebas dari unit root. Data yang stasioner dapat menghindari terjadinya fenomena regresi palsu (spurious regression) yang menjadikan koefisien hasil estimasi tidak valid akibat standard error yang bias. Uji stasioneritas dapat dilakukan menggunakan metode Augmented Dickey Fuller (ADF) test dan Phillips-Perron(PP) testdengan menyesuaikan tren deterministik yang dimiliki oleh masingmasing variabel yang digunakan. 
Pengujian

stasioneritas menggunakan metode Augmented Dickey Fuller (ADF) test dan Phillips-Perron(PP) test mengikuti persamaan $\Delta X_{t}=\beta_{1} X_{t-1}$, dimana $X$ adalah variabel tertentu dan $\beta_{1}$ adalah nilai Augmented Dickey Fuller (ADF) test atau Phillips-Perron(PP) test.

Pengujian hipotesa dilakukan terhadap $H_{0}: \beta_{1}=0$ (adanya unit root atau tidak stasioner) dan $H_{1}: \beta_{1} \neq 0$ (tidak adanya unit root atau stasioner). Jika nilai absolut ADF/PP lebih besar dari critical value $(\mathrm{CV})$ maka hipotesa $H_{0}$ ditolak dan berarti tidak terdapat unit root atau data stasioner. Sebaliknya, jika nilai absolut ADF/PP lebih kecil dari critical value $(\mathrm{CV})$ maka hipotesa $H_{0}$ diterima dan berarti terdapat unit root atau data

Tabel 2.

Hasil Uji Stasioneritas dengan Metode Augmented DickeyFuller (ADF)

\begin{tabular}{|c|c|c|c|c|c|}
\hline Variabel & $\begin{array}{l}\text { Uji } \\
\text { URT }\end{array}$ & $\begin{array}{c}\text { Tren } \\
\text { Deterministik }\end{array}$ & $\begin{array}{l}\text { ADF } \\
\text { Test }\end{array}$ & $\begin{array}{l}\mathrm{CV} \\
(1 \%)\end{array}$ & $\begin{array}{c}\text { Stasio } \\
\text { ner }\end{array}$ \\
\hline LnPGR & $\mathrm{I}(0)$ & $\begin{array}{l}\text { Konstanta, } \\
\text { tren linear }\end{array}$ & 12,724 & 3.993 & Ya \\
\hline LnNEER & $\mathrm{I}(0)$ & $\begin{array}{l}\text { Konstanta, } \\
\text { tren linear }\end{array}$ & $-7,475$ & $\begin{array}{c}- \\
3.993 \\
\end{array}$ & Ya \\
\hline \multirow[t]{2}{*}{ LnM2 } & $\mathrm{I}(0)$ & $\begin{array}{l}\text { Konstanta, } \\
\text { tren linear }\end{array}$ & $-4,588$ & $\begin{array}{c}- \\
3.993 \\
\end{array}$ & Tidak \\
\hline & $\mathrm{I}(1)$ & $\begin{array}{l}\text { Konstanta, } \\
\text { tren linear }\end{array}$ & $\overline{-}$ & $3, \overline{9} 93$ & Ya \\
\hline \multirow[t]{2}{*}{ IR } & $\mathrm{I}(0)$ & $\begin{array}{l}\text { Konstanta, } \\
\text { tren linear }\end{array}$ & $-2,061$ & $\begin{array}{c}- \\
3.993\end{array}$ & Tidak \\
\hline & $\mathrm{I}(1)$ & $\begin{array}{l}\text { Konstanta, } \\
\text { tren linear }\end{array}$ & $-9,140$ & $\begin{array}{c}- \\
3.993 \\
\end{array}$ & Ya \\
\hline
\end{tabular}

Sumber: Hasil Olahan, 2018

Catatan: I(0) mengindikasikan stationer pada level

I(1) mengindikasikan stasioner pada first defference tidak stasioner.

Selanjutnya, untuk memperkuat hasil uji stasioneritas metode Augmented Dickey Fuller (ADF) maka dilakukan metode Phillips-Perron(PP). Hasil pengujian metode Phillips-Perron(PP)pada derajat keyakinan $99 \%$ memperlihatkan hasil
Tabel 3. Hasil Uji Stasioneritas dengan Metode Phillips-Perron (PP)

\begin{tabular}{|l|c|l|c|c|c|}
\hline Variabel & $\begin{array}{c}\text { Uji } \\
\text { URT }\end{array}$ & $\begin{array}{c}\text { Tren } \\
\text { Deterministik }\end{array}$ & PP Test & $\begin{array}{c}\text { CV } \\
(1 \%)\end{array}$ & $\begin{array}{c}\text { Stasio } \\
\text { ner }\end{array}$ \\
\hline \hline LnPGR & $\mathrm{I}(0)$ & $\begin{array}{l}\text { Konstanta, } \\
\text { tren linear }\end{array}$ & $-12,537$ & $-3,993$ & Ya \\
\hline LnNEER & $\mathrm{I}(0)$ & $\begin{array}{l}\text { Konstanta, } \\
\text { tren linear }\end{array}$ & $-7,457$ & $-3,993$ & Ya \\
\hline LnM2 & $\mathrm{I}(0)$ & $\begin{array}{l}\text { Konstanta, } \\
\text { tren linear }\end{array}$ & $-4,568$ & $-3,993$ & Tidak \\
\hline $\mathrm{I}(1)$ & $\begin{array}{l}\text { Konstanta, } \\
\text { tren linear }\end{array}$ & $-16,227$ & $-3,993$ & $\mathrm{Ya}$ \\
\hline $\mathrm{IR}$ & $\mathrm{I}(0)$ & $\begin{array}{l}\text { Konstanta, } \\
\text { tren linear }\end{array}$ & $-3,071$ & $-3,993$ & Tidak \\
\hline & $\mathrm{I}(1)$ & $\begin{array}{l}\text { Konstanta, } \\
\text { tren linear }\end{array}$ & $-9,153$ & $-3,993$ & $\mathrm{Ya}$ \\
\hline
\end{tabular}

Sumber: Hasil Olahan, 2018

Catatan: I(0) mengindikasikan stationer pada level

I(1) mengindikasikan stasioner pada first defference yang sama dengan pengujian metode Augmented Dickey Fuller (ADF)dimana return harga emas (LnPGR) dan nilai tukar nominal efektif (LnNEER)telahstasioner pada tingkat level I(0). Sementara, jumlah uang beredar (LnM2) dan tingkat bunga (IR) baru stasioner padafirst difference, I(1). Karena semua data sudah stationer maka persamaan yang telah dispesifikasi sebelumnya dapat dilanjutkan kepengujian kointegrasi sebelum menggunakan metode ECM.

\section{Uji Kointegrasi}

Pengujian kointegrasi dilakukan untuk melihat hubungan jangka panjang antara variabel-variabel yang digunakan terutama derajat kointegrasinya pada I(1). Uji kointegrasi dalam penelitian ini untuk memvalidasi penggunaan metode ECM ketika variabel yang digunakan stasioner pada derajat integrasi 1, I(1). Selain itu, uji kointegrasi diperlukan pula untuk melengkapi uji stasioneritas yang telah dilakukan sebelumnya untuk menghindari regresi palsu.

Untuk menguji keberadaan hubungan kointegrasi penelitian menggunakan Johansen Cointegration test. Johansen Cointegration test menguji hipotesa apakah terdapat hubungan kointegrasi 
antar variabel full rank atau tidak. Pengujian kointegrasi dalam penelitian ini menjadi lebih penting lagi karena terkait dengan keharusan persyaratan pembentukan metode ECM yang berlandaskan pada teori ekonomi.

Pengujian kointegrasi memanfaatkan metode trace statistic dan eigenvalue dengan hipotesa nol dari pengujian cointegrating rank berikut:

$$
H_{0}: \lambda_{i}=0 \text {, dimana } i=r: 1, \ldots, n
$$

Penggunaan metode trace statistic dan eigenvalueperlu pula memperhatikan munculnya kemungkinan spesifikasi penentuan tren pengujian kointegrasi seperti no intercept dan no trend, intercept dan no trend, linear with intercept dan no trend, linear with intercept dan trend, dan quadratic with intercept dan trend. Hasil asumsi penentuan tren mengacu pada nilai kriteria akan menginformasikan banyaknya hubungan kointegrasi antar variabel sesuai dengan metode trace statistic dan eigenvalue.

Tabel 4. Hasil Uji Johansen Cointegration

\begin{tabular}{|c|c|c|c|c|c|c|}
\hline \multicolumn{7}{|c|}{ Johansen tests for cointegration } \\
\hline \multirow{2}{*}{\multicolumn{4}{|c|}{$\begin{array}{l}\text { Trend: constant } \\
\text { Sample: } 1997 \mathrm{~m} 11-2017 \mathrm{~m} 10\end{array}$}} & \multicolumn{2}{|c|}{ Number of obs $=$} & \multirow{2}{*}{$\begin{array}{r}240 \\
2 \\
\end{array}$} \\
\hline & & & & & Lags $=$ & \\
\hline $\operatorname{maxi}$ & & & & & $5 \%$ & \\
\hline mum & & & eigen & trace & critical & \\
\hline rank & parms & LL & value & statistic & value & \\
\hline 0 & 30 & 1038,28 & - & 403,18 & 68,52 & \\
\hline 1 & 39 & 1142,30 & 0,580 & 195,14 & 47,21 & \\
\hline 2 & 46 & 1202,28 & 0,393 & 75,18 & 29,68 & \\
\hline 3 & 51 & 1230,40 & 0,209 & 18,93 & 15,41 & \\
\hline 4 & 54 & 1239,15 & 0,070 & $1,44^{*}$ & 3,76 & \\
\hline 5 & 55 & 1239,87 & 0,006 & & & \\
\hline
\end{tabular}

Sumber: Hasil Olahan, 2018

Berdasarkan asumsi tren deterministik maka banyaknya hubungan kointegrasi antar variabel dengan trace statistic pada tingkat kepercayaan 95\% adalah 5 buah hubungan kointegrasi. Adanya hubungan kointegrasi memvalidasi penggunaan metode ECM dalam integrasi 1, I(1). Hubungan kointegrasi mengindikasikan adanya hubungan jangka panjang antara variabelvariabel ekonomi yang digunakan dalam penelitian ini.

\section{Tes Diagnostik}

Hasil uji normalitas menggunakan skewness/kurtosis (Jarque-Bera) menyatakan metode ECM berdistribusi normal.Hasil uji heterokedastisitas menggunakan metode Breusch-Pagan / Coo-Weisbert atau ARCH-test menyimpulkan metode ECM memiliki masalah heterokedastisitas. Oleh karena itu, untuk mengatasi persoalan heterokedastisitas maka penelitian ini menggunakan $V C E$ (robust).

Uji autokorelasi menggunakan metode Breusch-Godfrey LM dan DurbinWatson (DW) menyatakan model yang digunakan bebas dari masalah autokorelasi dan serial korelasi.RESET-test mengemukakan tidak adanya kesalahan spesifikasi dalam model regresi. Selanjutnya, hasil uji multikolineritas ECM dengan metode korelasi parsial antar variabel independen diperoleh nilai koefisien korelasi dibawah 0,85 sehingga dapat disimpulkan metode ECM bebas dari gejala multikolineritas.Sedangkan kemunculan structural break dari hasil Chow-test diatasi dengan menggunakan metode Phillips-Perron (PP) pada pengujian stasioneritas.

\section{Analisis Hasil Estimasi Error Correction Model (ECM)}

Estimasi Metode ECM ditujukan untuk melihat dinamika arah hubungan jangka pendek dan jangka panjang antara variabel sektor moneter dalam pergerakan return harga emas di Indonesia dalam periode 1997M9-2017M10. Variabel kebijakan 
moneter diproksi menggunakan jumlah uang beredar, tingkat bunga dan nilai tukar nominal efektif.

Hasil estimasi error correction model (ECM) jangka pendek dan jangka panjang dapat dituangkan dalam tabel berikut ini:

Tabel 5.

Hasil Estimasi Jangka Pendek dan Jangka Panjang Pergerakan Return Harga Emas, 1997M09-2017M10

\begin{tabular}{|c|c|c|}
\hline \multirow[t]{2}{*}{ Variabel } & \multicolumn{2}{|c|}{$\begin{array}{c}\text { Estimasi Error Correction } \\
\text { Model (ECM) }\end{array}$} \\
\hline & $\begin{array}{c}\text { Estimasi } \\
\text { Parameter }\end{array}$ & t-statistik \\
\hline Constant: $\alpha_{0}$ & 0,4951652 & $2,20 * *$ \\
\hline $\begin{array}{l}\Delta \ln N E E R_{t}: \\
\alpha_{N E E R}\end{array}$ & $-1,043254$ & $-15,50 * * *$ \\
\hline $\begin{array}{l}\Delta \ln M 2_{t}: \\
\alpha_{M 2}\end{array}$ & $-0,021084$ & $-0,14$ \\
\hline$\Delta I R_{t}: \alpha_{I R}$ & $-0,0002148$ & $-0,26$ \\
\hline$E C T: \gamma$ & $-0,9753366$ & $-24,33 * * *$ \\
\hline $\begin{array}{l}\ln N E E R_{t-1}: \\
\alpha_{N E E R, 1}\end{array}$ & $-0,0466665$ & $-1,93^{*}$ \\
\hline $\begin{array}{l}\ln M 2_{t-1}: \\
\alpha_{M 2,1}\end{array}$ & $-0,0185954$ & $-2,29 * *$ \\
\hline$I R_{t-1}: \alpha_{I R, 1}$ & $-0,0007086$ & $-3,19 * * *$ \\
\hline $\begin{array}{l}\text { Parameter } \\
\text { Jangka Panjang }\end{array}$ & & \\
\hline $\begin{array}{l}\ln N E E R_{t}: \\
\beta_{N E E R}\end{array}$ & $-0,0478466$ & $-2,00^{* *}$ \\
\hline $\ln M 2_{t}: \beta_{M 2}$ & $-0,0190657$ & $-2,37 * *$ \\
\hline$I R_{t}: \beta_{I R}$ & $-0,0007265$ & $-3,30 * * *$ \\
\hline Tes Diagnostik & & \\
\hline$R^{2}$ & 0,8693 & \\
\hline $\mathrm{D}-\mathrm{W}$ & 1,9919 & \\
\hline LM-Test & 0,029 & $(0,8640)$ \\
\hline ARCH-Test & 8,55 & $(0,0035)$ \\
\hline Reset Test & 1,70 & $(0,1672)$ \\
\hline Chow Test & 221,46 & $(0,000)$ \\
\hline
\end{tabular}

\begin{tabular}{|c|c|c|}
\hline Variabel & \multicolumn{2}{|c|}{$\begin{array}{c}\text { Estimasi Error Correction } \\
\text { Model (ECM) }\end{array}$} \\
\cline { 2 - 3 } & $\begin{array}{c}\text { Estimasi } \\
\text { Parameter }\end{array}$ & t-statistik \\
\hline
\end{tabular}

Sumber: Hasil Olahan, 2018

Catatan:

- Angka dalam kurung adalah p-value

- Standard error untuk mengestimasi tstatistik adalah heteroskedasticityrobust dengan VCE(robust)

- $\quad *, * *$, dan *** menyatakan signifikan pada level $10 \%, 5 \%$, dan $1 \%$

Estimasi menemukan nilai ECT (error correction term) sebesar -0,975 dengan probabilitas 0,000 . Ini berarti bahwa model spesifikasi ECM yang digunakan valid. Nilai koefisien ini mengimplikasikan perbedaan antara nilai aktual harga emas dengan nilai keseimbangannya sebesar $-0,975$ akan mengalami penyesuaian dalam waktu satu bulan pertama (karena datanya adalah bulanan). Kondisi ini dapat pula diartikan bahwa fluktuasi keseimbangan return harga emas pada jangka pendek akan dikoreksi menuju jangka panjang sebesar $97,5 \%$ pada bulan pertama dan 2,5\% pada proses penyesuaian dibulan-bulan berikutnya.

Hasil estimasi jangka pendek memperlihatkan hanya nilai tukar nominal efektif berpengaruh signifikan terhadap return harga emasi di Indonesia. Sementara, variabel jumlah uang beredar, dan tingkat bunga nominal tidak signifikan mempengaruhi pergerakan return harga emas. Nilai tukar nominal efektif berpengaruh negatif dan secara statistik signifikan terhadap return harga emas di Indonesia. Kondisi ini memperlihatkan bahwa depresiasi nilai tukar nominal efektif rupiah terhadap US dollar berbanding terbalik dengan return harga emas. Ketika nilai tukar rupiah terdepresiasi terhadap US dollar, return harga emas justru mengalami kenaikan.Kondisi ini mengindikasikan bahwa return harga emas di Indonesia 
sensitif terhadap volatilitas nilai tukar nominal efektif. Fakta seperti ini juga menjadi temuan Sjaastad (2008) dan The World Gold Council (2011) yang mengkaji pergerakan harga emas di Amerika Serikat untuk periode 1976 hingga 2010.

Dalam jangka panjang nilai tukar nominal efektiftetap berpengaruh negatif dan secara statistik signifikan terhadap return harga emas di Indonesia. Dampak perubahan nilai tukar nominal efektif terhadap return harga emas di Indonesia dalam jangka panjang sama dengan jangka pendek. Kondisi ini menandakan pentingnya memperhatikan volatilitas nilai tukar nominal efektif ketika ingin berinvestasi pada emas. Perlu diperhatikan bahwa depresiasi nilai tukar nominal efektif rupiah terhadap US dollar akan direspon secara negatif oleh pergerakan return harga emas. Ketika nilai tukar rupiah terdepresiasi terhadap US dollar, return harga emas justru mengalami kenaikan. Oleh karena itu, keputusan berinvestasi pada emas memerlukan pengetahuan pergerakan nilai tukar nominal efektif.Ketika nilai tukar nominal efektif mengalami depresiasi, emas dapat menjadi pilihan bagi investor sebagai pelindung nilai (currency hedge)untuk menghindari kerugian. Temuan ini sejalan dengan Wang dan Lee (2011) yang menguji dampak nilai tukar terhadap harga emas di Jepang dan Han, Xu and Wang (2008) yang menguji nilai tukar dollar Australia terhadap pergerakan harga emas.

Berbeda dengan pengaruh nilai tukar nominal efektif terhadap return harga emas di Indonesia, dampak jumlah uang beredardan tingkat bunga nominal hanya berpengaruh pada jangka panjang terhadap pergerakan return harga emas. Fakta ini mengindikasikan bahwa perubahan jumlah uang beredar dan dan tingkat bunga nominal tidak secara cepat direspon oleh perubahan return harga emas. Pergerakan return harga emas relatif lambat merespon perubahan jumlah uang beredar dan tingkat bunga.

Dampak negatif tingkat bunga terhadap return harga emas pada jangka panjang mengindikasikan opportunity memegang emas. Ini mengindikasikan bahwa semakin tinggi tingkat bunga, semakin rendah pula opportunity memegang emas. Temuan ini sejalan dengan hasil penelitian yang dilakukan oleh The World Gold Council (2011) sebelumnya terhadap data US dari tahun 1976 hingga 2010.Selanjutnya, secara spesifik temuan penelitian memperlihatkan dampak jumlah uang beredarberpengaruh negatif dan signifikan terhadap return harga emas pada jangka panjang, tetapi tidak tampak nyata pada jangka pendek. Temuan ini mengimplikasikan bahwa pada jangka pendek emas belum dapat berfungsi sebagai pelindung nilai dari kenaikan jumlah uang beredar, tetapi emas baru dapat bertindak sebagai pelindung nilai ketika jangka panjang. Kondisi ini mengindikasikan bahwa emas memiliki kemampuan daya beli dan kemampuan mempertahankan nilai ketika menghadap erosi sistem perbankan dan moneter (Bialkowski et al., 2013). Temuan ini didukung oleh penelitian yang dilakukan Dee, Li, dan Zeng (2013) di pasar China daratan.

Fakta menarik dari temuan penelitian ini adalah adanya hubungan negatif antara tingkat bunga nominal dengan return harga emas untuk jangka panjang di Indonesia. Temuan ini sesuai denganteori moneter klasik dimana kenaikan tingkat bunga nominal akan menurunkan return harga emas di Indonesia karena opportunity cost memegang emas menjadi meningkat. Hasil ini tidak menemukankehadiranGibson's 
Paradox $^{1}$ di Indonesia. Fakta ini diduga munculnya mekanisme alokasi emas untuk penggunaan moneter dan non moneter sebagaimana yang pernah dibahas oleh Barsky dan Summers (1988).Apalagi tujuan masyarakat memegang emas di Indonesia tidak hanya untuk berinvestasi, tetapi juga untuk tujuan konsumtif atau sebagai perhiasan (Irianto, 2007).

Sementara itu, peningkatan jumlah uang beredar dalam jangka panjang di Indonesia oleh Bank Indonesia mendorong investor untuk memegang emas. Keputusan investor memegang emas merupakan usaha pelindung nilai dari kesalahan mengantisipasi kesalahan kebijakan yang dapat mendorong inflasi. Temuan ini sejalan pula dengan temuan The World Gold Council (2011) dan Bailey (1988). Selain itu, kenaikan harga emas sebagai respon dari peningkatan jumlah uang beredar memberikan sinyal bahwa pasar mempunyai ekspektasi terhadap perputaran uang dimasa depan. Fakta yang sama juga ditemukan oleh Artigas (2010) yang meneliti US, Eropa, India dan Turki.

\section{SIMPULAN}

Penelitian ini telah menginvestigasi efek kebijakan moneter terhadap return harga emas di Indonesia menggunakan pendekatan error correction model (ECM) yang diturunkan dari single quadratic cost function yang memanfaatkan data bulanan sepanjang periode 1997M09 sampai dengan 2017M10. Pendekatan ECM memperlihatkan analisis jangka pendek dan jangka panjang dari dampak nilai tukar nominal efektif, jumlah uang beredar, harga saham, dan tingkat bunga riil terhadap pergerakan harga emas di Indonesia.

\footnotetext{
${ }^{1}$ Istilah ini pertama kali digunakan Keynes (1930)
}

Hasil estimasi jangka pendek memperlihatkan hanya nilai tukar nominal efektif berpengaruh signifikan terhadap return harga emas di Indonesia. Sementara, variabel jumlah uang beredar dan dan tingkat bunga nominal tidak signifikan mempengaruhi pergerakan harga emas pada jangka pendek. Sementara itu, hasil estimasi jangka panjang memperlihatkan semua variabel sektor moneter berpengaruh signifikan terhadap return harga emas di Indonesia. Fluktuasi keseimbangan harga emas pada jangka pendek akan dikoreksi menuju jangka panjang sebesar $97,5 \%$ dalam bulan pertama.

Dengan memperhatikan efek kebijakan moneter terlihat bahwa hanya nilai tukar nominal efektif saja yang berpengaruh signifikan baik pada jangka pendek maupun jangka panjang terhadap pergerakan return harga emas di Indonesia. Fakta ini memperlihatkan bahwa return harga emas di Indonesia sangat sensitif terhadap volatilitas nilai tukar nominal efektif. Oleh karena itu, keputusan berinvestasi pada emas memerlukan pengetahuan yang baik terhadap volatilitas nilai tukar nominal efektif rupiah terhadap US dollar. Dengan demikian investor dapat mendiversifikasikan aset porfolionya pada emas secara aman tanpa harus kehilangan kemampuan daya beli dan nilainya terutama pada saat terjadinya erosi pada sistem perbankan dan moneter. 


\section{DAFTAR PUSTAKA}

Apergis, N., and Papoulakos, D. (2013). The Australian Dollar and Gold Prices.The Open Economics Journal, 6, 1-10.

Artigas, J.C. (2010). Linking Global Money Supply to Gold and to Future Inflation. New York: The World Gold Trust Services, LLC, http://www.exchangetradedgold.co $\mathrm{m} / \mathrm{media} / \mathrm{ETG} /$ file/money supply_p aper_jan10.pdf

Bailey, W. (1988). Money Supply Announccements and the ex-ante Volatility of Asset Price. Money Credit Banking, 20, 611-620.

Barsky, R.B., and Summers, L.H. (1988). Gibson's Paradox and Gold Standard. The Journal of Political Economy, 96(3), 528-550.

Bialkowski, J.P., Bohl, M.T., Stephan, P.M., and Wisniewski, T.P. (2013). The Gold Price in Times of Crisis. Available at SSRN: http://ssrn.com/abstract $=1718106$ or http://dx.doi.org/10.2139/ssrn.17181 06

Ciner, C., Gurdgiev,C., and Lucey, B.M. (2013). Hedges and safe havens: An examination of stocks, bonds, gold, oil and exchange rates.International Review of Financial Analysis, 29, 202-211.

Dee, J., Li, L., and Zheng, Z. (2013). Is Gold a Hedge od a Safe Haven? Evidence from Inflation and Stock Market.International Journal of Development and Sustainability, 2, 12-27.

Domowitz, I., and Elbadawi, I. (1987). An error-Correction Approach to Money Demand: The Case of Sudan.Journal of Development Economics, 26(2), 257-272.

Eni, Y., dan Halim, J. (2014). Analisis Faktor-faktor yang Mempengaruhi Pergerakan Harga Emas Sebagai
Alternatif Investasi Di Indonesia. BINUS University: Laporan Teknis.

Irianto, G. (2007). Pengaruh Bunga Deposito, Kurs Rp/US\$ dan Harga Emas Terhadap Indeks Harga Saham Gabungan (IHSG). Jurnal Manajemen Mutu, 6(2), 155-164.

Johansen, S. (1995). Likelihood-Based Inference in Cointegrated Vector Auto-Regressive Models. Oxford University Press.

Gujarati, D. (2003). Basic econometrics, $4^{\text {th }}$ edition. Singapore: McGraw-Hill Book Co.

Han, A., Xu, S., and Wang, S. (2008). Australian Dollars Exchange Rate and Gold Prices: An Interval Method Analysis, The $7^{\text {th }}$ International Symposium on Operations Research and Its Applications (ISORA'08), Lijiang, China, October 31-November 3.

Keynes, J.M. (1930). A Treatise on Money. MacmillanISBN0-404-15000-4.

Phillips, P.C.B., and Perron, P. (1988). Testing for a unit root in time series regression. Biometrika, 75(2), 335346.

Sjaastad, J. (2008). The Price of Gold and Exchange Rates: Once Again, Resource Policy, 33(1), 118-124. 
Sunariyah. (2006). Pengantar

Pengetahuan Pasar Modal, $5^{\text {th }}$ edisi. Yogyakarta: UPP-STIM YKPN.

The World Gold Council (2011). The Impact of Inflation and Deflation on The case for Gold.Oxford Economics.https://www.gold.org/res earch/impact-inflation-anddeflation-case-gold-report

Wang, K.M., and Lee, Y.M. (2011). The Yen for Gold.Resources Policy, 36, 39-48. 